\title{
Sense of Balance in Indian Conceptualisation of Psychological Well-being
}

\section{Poczucie równowagi w indyjskim ujęciu dobrostanu psychicznego}

\author{
Joseph Jeyaraj Swaminathan ${ }^{1,2}$, Giuseppe Crea ${ }^{1}$, Zbigniew Formella ${ }^{1}$ \\ ${ }^{1}$ Institute of Psychology, Salesian Pontifical University in Rome, Italy \\ ${ }^{2}$ Don Bosco Institute of Psychological Services in Chennai, India \\ ORCID JJS https://orcid.org/0000-0002-8127-1245; GC https://orcid.org/0000-0002-7860-0730; ZF https://orcid.org/0000-0003-2846-0992 \\ - jeyaraj67@yahoo.com \\ Received: 3 Oct, 2021; Revised: 25 Nov, 2021; Accepted: 6 Dec, 2021
}

\begin{abstract}
The concept of psychological well-being (PWB) engages the attention of those who live in the Global North, as well as those in the Global South. Similar to the Western concept of PWB, its Indian conceptualisation too, has a long history dating back to at least 3,000 years. This article accentuates that, in India, a 'sense of balance' (sama in Sanskrit) is an overarching principle that guides ecological, social, and personal well-being. This sense of balance is discussed in the exposition of concepts, such as hedonia and eudaimonia, which are found in both the Western and Indian concept of PWB. Major differences include the collectivist nature of Indians, their emphasis of spirituality and their belief that suffering and happiness are two dimensions of a single reality. Through a comparative narrative method, it is evidenced that Indian constructs, namely, Sama, Dharma, Sattva, Rajas and Tamas resonate meaningfully with universal principles, such as ethical living, social commitment, and spiritual awareness. In short, Indian conceptualisation of PWB holds that it is holistic, integrated, and balanced. An extended prospect of this sense of balance is its appropriateness in enabling people to achieve ecological balance, irrespective of their cultural affiliations.
\end{abstract}

Keywords: well-being, India, Indian psychology, sense of balance, collectivist society, sama, trigunas, hedonia, eudaimonia

Streszczenie: Pojęcie dobrostanu psychicznego (PDP) przyciąga uwagę zarówno tych, którzy mieszkają na Globalnej Północy, jak i tych na Globalnym Południu. Podobnie jak zachodnia koncepcja PDP, jej indyjski odpowiednik ma długą historię, sięgającą co najmniej 3000 lat. Opracowanie to podkreśla, że w Indiach "poczucie równowagi” (sanskryt sama) jest nadrzędną zasadą, która kieruje dobrostanem ekologicznym, społecznym i osobistym. To poczucie równowagi jest omawiane w oparciu o takie pojęcia jak hedonizm i eudajmonia, które można znaleźć zarówno w zachodniej, jak i indyjskiej koncepcji PDP. Główne różnice obejmują kolektywistyczną naturę Hindusów, ich nacisk na duchowość oraz to, że cierpienie i szczęście są dwoma wymiarami jednej rzeczywistości. Dzięki porównawczej metodzie narracji dowiedziono, że takie indyjskie terminy, jak Sama, Dharma, Sattva, Rajas i Tamas, w znaczący sposób korespondują z takimi uniwersalnymi zasadami, jak etyczne życie, zaangażowanie społeczne i świadomość duchowa. Podsumowując, indyjska konceptualizacja PDP głosi, że jest ona holistyczna, zintegrowana i zrównoważona. Rozszerzoną perspektywą tego poczucia równowagi jest jego adekwatność w umożliwianiu ludziom osiągnięcia równowagi ekologicznej, niezależnie od ich przynależności kulturowej.

Słowa kluczowe: dobrostan, Indie, indyjska psychologia, poczucie równowagi, społeczeństwo kolektywistyczne, sama, trigunas, hedonizm, eudajmonia 


\section{Introduction}

Understanding the constituent elements of happiness and well-being is a common quest of all cultures from ancient times. The early philosophical schools of both the East and the West have tried to explain this concept. They proposed that wealth, fulfilling one's wishes, relationships with others, furthering one's interests, developing one's potential, adherence to a value system, following the Faith of one's choice, and personal spirituality, are essential characteristics of well-being (Salagame 2003). It is clear that this description proposes well-being to be holistic in nature and encompassing all aspects of life. This sense of balance was very well expounded by the World Health Organisation (WHO), when it defined positive mental health as, "a state of well-being in which the individual realises his or her own abilities, can cope with the normal stresses of life, can work productively and fruitfully, and is able to make a contribution to his or her community" (WHO 2001, 1).

Is material wealth the ultimate indicator of well-being? In the West, from ancient philosophers, such as Aristotle, to the $2 \mathrm{O}^{\text {th }}$ century Utilitarian philosophers, many had reiterated that although material wealth was an important aspect of happiness, it could not be the only yardstick, with which to measure the holistic well-being of countries and its citizens. They attest that a society, which concentrates purely on a high level of material prosperity, may not be capable of providing psychological and spiritual well-being (Salagame 2003). A review of a number of studies on the association between economic growth and well-being among rich nations, had persuaded psychologists to conclude: "Our becoming much better off over the last four decades, has not been accompanied by one iota of increased subjective well-being" (Myers 2000, 61).

In India, sages and philosophers have always held that the source of happiness must be found from within the self, and not from the outside (Salagame 2003; Diener and Suh 200o). The concept of interior happiness has influenced the Indian cultural ethos so much that people tend to find happiness, even when they lack material wealth. Diener and Diener's study (2000) observed that on a scale ranging from o to 100 , while India's purchasing power parity (PPP) had a low score of 5 , when compared with the USA that had a PPP score of 100 , there was very little difference between the two countries in their mean life satisfaction. While in India, it was 6.70 on a scale ranging from 1 (dissatisfied) to 10 (satisfied), the mean life satisfaction among Americans was only 7.73 (Salagame 2003).

It does seem that a materialistic worldview is at the heart of our present crisis. Furthermore, the lack of an integrated and balanced cosmic and ecological worldview tends to alienate human beings from the world. Egmond and Vries $(2011,853)$ insist: "this integral worldview is defined by the vertical contrast between idealism and materialism, and the horizontal contrast between uniformity and diversity". To better understand this concept, let us delve into the specific contribution of Indian philosophical and psychological traditions.

\section{Indian Philosophical conceptualisation of well-being}

Indian philosophy shares a common framework with Indian psychology in such a manner that its philosophical worldviews synchronise with the psychological concepts of happiness and well-being (Bhawuk 2011). Scholars attest that although Indian psychology gained its importance only in the twentieth century, its fundamental principles are rooted in the Vedic and Upanishadic periods. These concepts evolved over a period of time between 3,00o B.C. to 1,00o B.C. when sages and philosophers were believed to have cognised intuitively, the intrinsic nature of the world, human beings, the purpose of human existence, etc., and which they expressed in the form of hymns and discourses. These were considered to be revealed truths, and these texts were deemed 
to be sacred and inviolable (Bhawuk 2011; Salagame 2003).

While discussing Indian philosophical thinking, it must be clarified that the "Western usage of the term is connotatively different from how philosophy is understood in India" (Salagame 2016, 4). Indian philosophy cannot be limited to mere cognitive exercise; rather, it is a combination of reflective thinking and lived experience. Indian philosophy is a corpus of knowledge that reflects on lived beliefs and experiences, on fundamental principles of life, such as moksha (salvation), jiva (soul), punarjanma (rebirth), karma (destiny), etc., and the lived experience of day-to-day living (Bhawuk 2011; Singh 2019). An important fact about Indian philosophical tradition that many Westerners find it hard to comprehend, is that no hard and fast distinction is accorded when discussing fundamental principles such as religion, philosophy, spirituality, and everyday life in India. All these concepts are interwoven as one whole, as a integrated factor of life (Salagame 2016; Singh 2019).

The Indian philosophical system holds an expanded worldview regarding psychology, stating that it is not only a science of human behaviour, but also a study of human possibility and progress. According to this worldview, all living beings, humans, animals, plants are all interconnected and interdependent. So Indian psychology is positive in nature, inclusive and holistic, focussed on the attainment of total well-being (Tandon 2016). Indian philosophers and psychologists taught that human beings should focus on the realisation of the eternal (nithya) and permanent (satya) rather than those realities that are momentary (kshantika), liable to be destroyed (kshara), and impermanent (mithya). They applied this distinction for reflecting on everything in the universe; physical realities, biological entities, psychological attributes, moral values, and spiritual quest. This same distinction was utilised in evaluating what is good and bad, worthy and unworthy, and what is desired and undesired. Thus, well-being was also judged by the same criterion (Salagame 2003).

\subsection{Hedonia and eudaimonia in Indian philosophy}

To understand the Indian conceptualisation of psychological well-being, we will be referring to Vedic-vedantic philosophy's idealistic concepts, Samkya-yoga philosophy's dualism, and the Buddhist pragmatic philosophy of becoming. It is interesting to note that hedonia and eudaimonia taught by early Greek philosophers, were also taught in the early Indian philosophical schools. Based on those different schools, three contrasting approaches can be delineated; hedonic, transcendent and collective, each of them based on the view of human nature, and that of the world. Philosophers in the West define hedonia as, "an ethical position which claims that pleasure or happiness is the highest or most intrinsic good in life, and that people should pursue as much pleasure and as little pain as possible" (Bunnin and Yu 2004, 298-299). In India, 'hedonic perspective' was expounded by the charvaaka school whose epistemology is based on positivism. Positivists acknowledge as real only those that can be perceived and deny the existence of anything that cannot be perceived.

The charvaaka philosophy is materialistic in its worldview and propagated the fulfilment of sensory desires as the sole criterion for well-being. Therefore, it rejects the notion of God, dharma (values), and the law of karma (theory of rebirth as the consequence of one's actions). It also denies the existence of transcendent Self or Consciousness, which is termed as Atman in Indian philosophy. Hence, people should do whatever is possible to maximise pleasure and avoid pain (Raju 1992; Salagame 2003). This is very similar to the Western concept of hedonia, especially that of Aristippus (Joshanloo 2014). Although some claim that in the West, hedonic principles supersede the eudaimonic principles, positive psychology has a well-rounded theory of eudaimonia and well-being. However, systematic and 
scientific attempts are being made to understand the integration of the two (Huta 2018; Joshanloo 2014).

Some Indian philosophical and Vedic traditions, explained in Upanishads and Bhagavad Gita, recognise another view of human existence called 'transcendental perspective' that provided a comprehensive view of human life and its goals, which is similar to the 'eudaimonic perspective' of the West (Salagame 2003; Salagame 2004). Many of the characteristics of transcendental perspective has its parallels in the eudaimonic well-being, as described by Ryff (1989). These notions are similar to the concept of daimon, the principle of good living that Aristotle had described in his Nicomachean Ethics (Irwin 1994). Both the eudaimonic tradition of Aristotle and the Indian transcendental perspective of life affirm that people can experience well-being only when they possess an expanded consciousness and live a disciplined life (Huta and Ryan 2010; Ryff 1989; Salagame 2016).

Eudaimonic principles had played a key part in the Indian conceptualisation of happiness and well-being. Most Indian philosophical schools advocated eudaimonic principles that encouraged virtuous and righteous living, rather than seeking hedonic pleasure (Shamasundar 2008). A key concept in Indian philosophy is dharma which is central to the understanding of living a virtuous life. "Dharma is the principle that governs the universe, society, and individual lives - the supreme and all-encompassing regulatory principle. The whole world and human affairs are controlled and operated by dharma" (Joshanloo 2014, 478). The one who lives a virtuous life is said to act in accord with dharma.

Here too, there is a similarity between the Western and Indian philosophical traditions. Dharma in Indian philosophy is similar to the concept of daimon of eudaimonia, but it is also different, because the concept of dharma is more overarching and holistic. While daimon is said to regulate an individual's way of life, dharma regulates the order in this world, so that individual actions would not disrupt the harmony between individual soul and cosmic order. For example, an individual's behaviour should not disturb the vegetation, animal, and ecological systems, and therefore, everyone is required to practise cardinal virtues such as gratitude, compassion, non-violence, and generosity. Therefore, according to the Vedic-vedantic tradition, only when people base their life on dharma, can they transcend this material world and attain moksha (salvation or liberation). It must also be added that Yoga and Samkhya schools try not to negate the world, instead, they propose to find liberation, and through the world and the body. In short, a satisfied state of mind and the practice of virtues are the key elements of happiness and well-being (Joshanloo 2014; Salagame 2003).

\subsection{Difference between Western and Indian concept of well-being}

The Western perspective of well-being underwent a gradual transformation in shifting the importance from the concept of happiness to that of well-being. In fact, the concept of well-being had to transcend from mere positive affectivity and hedonic happiness to a wholesome affective balance (Bradburn 1969). This change of mind-set was well portrayed by Martin Seligman in his book, Flourish (2011), wherein he explains how his perspective on happiness had changed within 10 years of writing Authentic happiness (2002). In 2002, he thought that happiness was the central aspect of positive psychology, and the gold standard for measuring happiness was life satisfaction. Yet, within a span of 10 years, he realised that people wanted to experience well-being rather than merely happiness: "Life satisfaction essentially measures cheerful mood, so it is not entitled to a central place in any theory that aims to be more than a happiology" (Seligman 2011, 14). Thus, Seligman and other positive psychologists began to deny importance to the notion of happiness and 
declared flourishing as the new gold standard of well-being.

While some from the Western perspective considered well-being as an optimum level of happiness in bio-psycho-social aspects of life, Indian Vedic-vedantic wisdom considered sat-cit-ananda as the ultimate measure of well-being (Singh, Raina and Sahni 2017). Bradburn's (1969) concept of balance of positive and negative affect as the indicator of well-being, has brought about much discussion in the West. While positive emotions and negative emotions were considered generally as opposites, people in Japan and India consider happiness as encompassing both positive affect and negative affect (Ryff et al. 2014; Kitayama, Markus and Kurokawa 2000).

Although the charvaaka school had propagated hedonic philosophy as the norm, most other philosophical and religious traditions of India advocated 'happiness' that was permanent and transcendental. For example, Buddhism holds that genuine happiness is possible, only when it is independent of any internal or external pleasurable stimuli (Wallace and Shapiro 2006). Buddhist tradition rejects hedonic happiness because happiness based on pleasure is temporary, makes an individual selfish, and is in conflict with the well-being of others (Joshanloo 2014; Ricard 2011). It also teaches that persons who derive enjoyment from sensual pleasures, such as visual images, good music, aromas, and tactile sensations, would experience a feeling of emptiness when these external stimuli are absent. Likewise, happiness gained from being acknowledged, praised, respected, and loved, are all fleeting sensations that are transient (Wallace and Shapiro 2006). Buddhist philosophy claimed that hedonic happiness causes a person to desire for material pleasures, which is the root cause of all suffering (Chen 2006).

\subsection{Collectivist perspective of well-being in India}

Indian cultural ethos is said to be governed by a 'collectivist mentality' that is concerned with "the universal and perennial concern for the well-being of the entire mankind" summarised in these words; "let everyone be prosperous, and let no one think of the unhappiness of anyone" (Sinha 1990, 1). Studies have shown that people belonging to collectivist cultures, tend to draw support and energy from their interdependent sense of self, and perceive their worth based on interpersonal rapport with their close relations (Christopher 1999; Oishi 2018). This collective cohesiveness so enhances their well-being that "individuals in interdependent cultures come closer to realising their cultural ideals by self-effacing, thereby, removing their distinguishing and potentially alienating features, and allowing them to maximise their sense of belongingness" (Heine and Lehman 1995, 605).

Indian seers had affirmed that a vast majority of Indians possessed a collectivist mentality, and hence, they formulated the social framework to enhance collective well-being rather than individual well-being (Bhawuk 2011; Salagame 2003). Their individual goals are submerged within the collective goal of a group, or the society to which they belong (Triandis 1995). In collectivist cultures, people tend to have an interdependent concept of self, which includes close members of the family, friends, neighbours and co-workers. Contrastingly, people belonging to individualist cultures, tend to have an independent concept of self, which enjoins them to care for their personal well-being before considering that of family members, friends, relatives, and people at the workplace (Bhawuk 2011; Markus and Kitayama 1991). Importantly, Indian children are taught to already attain a collective identity, during their initial socialisation process (Shukla 2016).

While the Western perspective of well-being was embodied by individualistic qualities, such as self-esteem, self-mastery, self-determination, autonomy and self-control, Indian collectivist outlook focussed more on obedience to elders, self-sacrifice, family ties, and adherence to traditions and customs (Joshanloo 2014; Salagame 2016). Studies show 
that those from individualistic cultures, enjoy an optimum level of life satisfaction, because they manage to acquire personal gains or accomplishments. People from collectivist cultures experience a lower level of life satisfaction, but higher levels of well-being, because they focus on relational and communal aspects of life (Salagame 2016).

One of the ultimate truths taught by $A d$ vaita vedanta is that 'all of us are one' and that in its purest form, the human spirit (atman) becomes the same as the divine spirit (brahman). Consequently, the ultimate goal of all humans is to realise this oneness and strive to bring peace and harmony into the lives of everyone. Therefore, Indians experience greater well-being, as they base their happiness on collective well-being rather than on personal well-being. So, it is normal for Indians to sacrifice their personal goals and career opportunities, in order to fulfil their family needs. This happens due to the narrowness of the boundaries between self and others, and they experience a "a less rigid and amorphous boundary (Bhawuk 2011, 12). The fourteenth Dalai Lama expressed it succinctly with this remark: "The more we care for the happiness of others, the greater our own sense of happiness becomes" (Mitchell and Wiseman 2003 as cited in Joshanloo 2014, 479).

\section{Spiritual conceptualisation of well-being in India}

Spirituality in India, along with philosophy, has been emphasised for more than 2,500 years, a fact corroborated by the number of spiritual masters, who have lived in India from $600 \mathrm{BC}$ up to the present time. They belonged to different castes, originated from different parts of India, and belonged to different religions such as Hinduism, Buddhism, Jainism, Sikhism, Islam, and Sufism. Spirituality in India is considered to be both a spiritual and a cultural phenomenon. It is for these reasons that Bhawuk asserted: "Spirituality is valued in the Indian tradition since time immemorial" $(2011,25)$.
Indian conceptualisation of spiritual well-being, known as 'transcendental perspective', is considered to be the highest form of well-being, and contrary to the hedonic perspective. Spiritual well-being promotes a holistic vision of the world and aspires to bring about the well-being for all people without any distinction. Guiding principles of this school of thought dictate that only those who possess pure consciousness (Atman or shuddha chaitanya), would attain a holistic and transcendental well-being. This state of pure consciousness would lead to Ananda, which people manifest through positive feelings that are not conditioned by external sources, but by implicit good qualities. Only such people are thought to be capable of experiencing a sublime, peaceful, and positive state of mind, termed as shaanti (peacefulness). Although Ananda is often intended as another-worldly concept and an ideal to arrive at, there are some Indian philosophers who claim, "a person who has an expanded state of consciousness evaluates his/her well-being as Ananda" (Salagame 2003, 5).

\subsection{Indian spirituality and well-being}

Indian sages, as well as philosophers, have described spirituality as an innate quality found in every human being, and that it is the best means to attain happiness. In the well-being tradition of India, spirituality is considered to be the path through which one experiences meaning and purpose of life, experiences a deeper connection with others, and nature, and thus, transcends his egocentric relationship with the world. Thus, striving for happiness is considered to be a spiritual pursuit of turning inwards, and realising one's true self (Salagame 2003).

The discussion among Indian philosophers and psychologists regarding happiness and well-being, has largely centred on either fulfilling desires and avoiding suffering (extrinsic sources), or cultivation of a spiritual state of consciousness (intrinsic sources). Hindu tradition extolled the spiritual dimension, because it allowed a human being 
to go beyond the dualism of pleasure and pain and arrive at a state of enlightenment (Salagame 2016). Taittiriya Upanishad describes several layers of happiness and differentiates sukha (happiness) from ananda (bliss). While sukha means 'agreeable feelings', caused by a happy feeling in the sense organs and the mind (Mishra 2017), ananda means "bliss", which is "associated with spirituality" (Salagame 2016, 5). All spiritually inclined people strive to attain ananda and not merely sukha during their life journey. Such people would also experience an inner happiness that comprises of satchit-ananda, meaning truthfulness-awareness-bliss (Joshanloo 2014; Salagame 2003).

Spiritual practices play a very important role in Indian spirituality, both to honour God and to attain personal fulfilment. Yoga, meditation, and different forms of prayer are recommended in order to discipline the mind, body, and to achieve a balance between the experience of happiness and practice of virtues in one's daily life (Ricard 2011; Joshanloo 2014). Though we cannot equate the Indian concept of spiritual well-being to positive psychology in its entirety, it is possible to say that some of the spiritual practices proposed in Indian traditions are similar to the virtues proposed by positive psychology namely, wisdom, knowledge, courage, justice, transcendence, humanity, etc. (Seligman 2011).

Bradburn's affect balance theory was effectively practised in Indian culture many centuries before, albeit in the spiritual sphere, rather than in the philosophical or psychological strata that Western culture had discussed it (Diener 1984; Kraut 2015; Ryff 1989; Waterman 1990). Two concepts from Indian philosophy explain this idea of balance in life: firstly, nishkamakarma is a highly spiritual and self-transcending concept that required a person to give up the fruits of their labour with a detached mind; secondly, sthitaprajna is a state of complete balance and harmony. In fact, sthitaprajna was considered to be a higher state of existence, wherein an individual would transcend their thoughts, feelings, behaviour, and also happiness, in order to reach bliss (Bhawuk 2011).

\subsection{Indian spirituality is inclusive of suffering}

Indian spirituality teaches that happiness and sadness are two sides of the same coin. Indian spirituality deals with the dualities of life such as birth and death, good and evil, pleasure and pain (Salagame 2006). There are said to be two important aspects in Indian spirituality: the first is the experience of the transcendental, which consists of paranormal and spiritual states of consciousness; the second is living a value-based way of life, which would cause pain and suffering. Indian Spiritual masters had taught that whenever people strive to transcend their sensual experiences to live a life of transcendence, they are prone to experience pain and suffering (Salagame 2006; Singh 2019). One important aim of Indian spirituality is to assist people to respond to human suffering, and as the Indian collectivist tradition affirms, the best response is to share in each other's suffering (Joshanloo 2014; Ricard 2011; Wallace and Shapiro 2006).

Hindu and Buddhist traditions also claim that true well-being can be experienced, only when one understands that happiness is not distinct from sadness, suffering, and tragedy. In fact, the Buddhist tradition reiterates that to understand the true meaning of happiness and sadness, one must desist from accepting one and rejecting the other (Ricard 2011). According to Indian spiritual tradition, the interplay of spirituality and suffering is considered to be positive rather than negative, life-enhancing rather than destructive. This way of life would help an individual to find the ultimate meaning of life, and become aware of the Sacred, thereby leading to a sense of connectedness with the divine. Moreover, when people understand this interplay of spirituality and suffering, their life takes a positive direction, they discover the purpose and meaning of their lives, and feel a sense of belonging to the community.

As we move on to the discussion on the concept of balance, it must be noted that 
the impact of social lifestyle, characterised by collectivist cultural identity and spirituality that recognised suffering as an integral part of human existence, are essential to understand the concept of balance in psychological well-being.

\section{The concept of balance (Sama) in Indian well-being}

The traditional conceptualisation of well-being in India is related to adjustment and balance between health, homeostasis, quality of life, capacities and beliefs. The Indian concept of well-being takes into consideration socio-cultural elements and the impact of environment on their quality of life. Thus, psycho-social well-being in the Indian tradition is characterised by people's capacity to adapt to the environment in such a manner as to experience equilibrium. This sense of equilibrium is described as sama (Sinha 1990). This interplay of day-to-day stresses and the demands made by the environment is similar to the P-E fit theory (Caplan 1987; Edwards and Cooper 2013) that we had discussed in the second chapter of this study. The concept of sama includes health, moral values, personal characteristics, eschatological consequences, and social well-being.

Classical Indian conceptualization of well-being regarded balance in both physical and mental health as essential ingredients. While the concept of mental health was closer to that of psycho-social well-being, health, in general, had more of a wider perspective: It is worth observing that health was conceived in a very wide sense, which comprised the total well-being and happiness. It was not only equated with the possession of health and absence of ailments, but cultivation of certain psychological qualities, personality characteristics, and intellectual and moral values like memory, intelligence, freedom from inner conflicts, absence of carelessness, devotion to knowledge, control of impulses, envy, and conceit, serenity, truthfulness and the like were considered as its essential constituents (Sinha 1990, 4).

\subsection{Balance as an element of social well-being in India}

Indian psychologists have reiterated that self is "an ontological entity" (Bhawuk 2011, 68), which is intricately connected with physical, social, psychological, and metaphysical dimensions of self. Studies have revealed that the core and the essence of the Indian concept of self is metaphysical, which is termed as Atman (the real self) by philosophers and psychologists. In contrast to the Western concept of homeostasis (Selye 1965; Lazarus 1993) which considered only the physiological and psychological dimensions, the Indian tradition believes that a person can experience balance in life, only when individual characteristics and social characteristics are realised together. The social self consists of elements that are included in the physical and psychological self, but it is complete only when social relationships and interactions are included in it. This integrated social self consists of both independent and interdependent concepts of self. As has been accentuated earlier, this concept of integration is the basis on which the collectivist perspective of Indian culture is founded (Bhawuk 2011; Triandis 1995).

According to Samkhya philosophy of Kapila, earthly life is a combination of both joys and sorrows and a mixture of pleasure and pain. It teaches that pain is inevitable and lists three types of pain that affect an individual's well-being, namely, adhyatmika, adhibhautika and adhidaivika, which are explained as follows: The first is due to intra-organic causes like bodily disorders and mental affections which include bodily pains, pangs of fear, anger, greed, and so on. The second is produced by extra-organic natural causes like snake-bite, pain on being hit by objects, murder, and so on. The third kind of suffering is caused by extra-organic supernatural causes like pain inflicted by ghosts, demons, and so on (Sinha 1990, 5).

Samkhya philosophy teaches that although people strive to get rid of pain and enjoy only happiness, it is natural that happiness and sadness co-exist. It further affirms that people could enjoy well-being, if 
only they maintain some kind of balance or equilibrium. These ideas evidence palpable similarity with Bradburn's concept of affect balance (1969), and the balanced affect model of Francis (Francis et al. 2005; Francis et al. 2015; Francis, Laycock and Crea 2017). Samkhya philosophy describes the concept of balance as the ontological dualism of the self, manifested in two fundamental categories namely, purusa, which is the unchanging core, and is equated to the soul and prakriti, the tangible and material aspect of the self. Purusa is the ideal state of existence, and is compared to a pure light, which is not affected by pleasure or pain. It cannot be tied down to the material world or affected by everyday experiences. Instead, the manifestation of the self, and also the everyday experiences of the external world, are all carried out by prakriti. In short, it is the apparatus through which one experiences the world (Anuradha and $\mathrm{Ku}$ mar 2015; Sinha 1990).

\subsection{Balance among three types of personality characteristics}

Indian philosophical traditions like the Samkhya school, Vedanta and Buddhist tradition, as well as medical texts like Ayurveda, assume that physical, mental, and spiritual elements make up an individual's personality (Jha 2009). However, as Prakriti is the tangible manifestation of the self, and comprises the physical body, sense organs, the mind, and all its functions, such as reasoning, reflection, and memory. This prakriti is constituted by three fundamental elements that exist with various combinations in all physical and psychical objects of the universe. These three fundamental elements sattva, rajas and tamas are called gunas. This word guna can be translated as a "quality" or an "attribute" of a person. Total well-being is possible, only when these three (trigunas) exist in absolute balance (Anuradha and $\mathrm{Ku}$ mar 2015).

Samkhya philosophy promulgated the trigunas perspective to describe human nature and specifically, human personality:
"The triguna theory is the Indian theory of personality" (Anuradha and Kumar 2015, 196). The above mentioned gunas, namely, sattva, rajas, and tamas are present in each individual and get manifested as personality traits. For this reason, the trigunas personality theory is termed as "the Indian understanding of the trait theory of personality" (Anuradha and Kumar 2015, 197). According to this theory, sattva is the element of happiness and illumination, rajas is the principle of activity, which on the affective side is the reason for all pain (dukha), and tamas is the principle of passivity which obstructs one's intellect and produces ignorance and confusion (Sinha 1990; Singh et al. 2016). This has been defined succinctly by Sinha: "It is the state of samyavastha or equilibrium of the three that holds the secret to an individual's well-being" $(1990,5)$.

In describing personality, the trigunas perspective declares that at birth all three $g u$ nas are present in everyone. In general, one of the gunas predominates over the other two, and it is an individual's actions and experiences that determine which of the gunas become pre-dominant. It is this predominant guna that determines an individual's characteristic personality. Sattva guna is representative of serenity, tranquillity, purity, and idealistic mode of existence. It enkindles unconditional love, moments of inspiration, quiet joy, and calmness born out of silence and meditation. Rajas guna is identified by its continuous movement, restlessness, feverish activity, passionate commitment and outbursts of anger. It can also inspire people to constructive and energetic activity, courage in moments of crisis, and enthusiastic enterprises. Tamas guna is the element of solidity, inertia, and resistance. An individual with a preponderance of tamas would be slothful, obstinate, and would give in easily to despair (Anuradha and Kumar 2015).

Research on this Indian concept of personality has shown that sattva guna is strongly correlated with satisfaction in life and positive organisational behaviours. While rajas guna was positively correlated with 
professional satisfaction, tamas guna was negatively correlated. The qualities manifested by sattva guna indicate that those who possess sattva personality are most likely to experience occupational well-being (Anuradha and Kumar 2015; Biswas 2010). However, Indian philosophical tradition holds that transcendence or liberation is getting back to the original state of complete balance of the three gunas (Anuradha and Kumar 2015; Singh et al. 2016). A study of 100 Indian University students showed that sattva guna was significantly correlated to emotional well-being, flourishing, and predicted psychological well-being, while rajas and tamas guna were negatively correlated (Sharma, Singh and Mehrotra 2016).

A number of studies have been conducted on the role of rajas guna in occupational satisfaction. It has been found that passion, the central quality manifested in rajas is responsible for an individual's occupational well-being. Vallerand and colleagues defined passion as a "strong inclination or desire toward an activity that one likes, finds important, and in which one invests time and energy" (2003, 757). Citing various literature reviews Anuradha and Kumar (2015, 198) state that rajas guna includes two types of passion: harmonious passion and obsessive passion. Those who manifest harmonious passion (engaging in activity due to personal choice, and for a noble purpose) are shown to have higher satisfaction (Thorgren et al. 2013), lower depression (Houlfort et al. 2014) and lower levels of burnout (Lavigne et al. 2012). Those who manifest obsessive passion (engaging in an activity out of compulsion) tend to adapt badly to occupation stresses (Ho and Pollack 2014).

The Indian perception of personality offers a multi-cultural perspective and assists in comparing the Western and Eastern perspectives. It is also important to remember that Indian psychological thought holds that human beings are constantly evolving, transforming, and growing in their journey towards self-realisation. The trigunas perspective holds that personality is not fixed forever, and that it is possible to change one's personality. A sattva personality can become a rajas personality, on account of life experiences and individual inclinations. Similarly, it is possible that a rajas personality acquires either a sattva or tamas personality (Anuradha and Kumar 2015).

\subsection{Simultaneous existence of opposites and ecological well-being}

In the philosophical tradition of India and other Eastern countries, the simultaneous existence of opposite entities is discussed in various disciplines, very well manifested, especially in Indian mythology, ethics, well-being, music, personality, and social values. Importantly, the concept of simultaneous presence is very important in the eastern understanding of well-being, as well (Bhawuk 2011). The Taoist concept of well-being is similar to what other Asian philosophical schools, such as the Indian and Japanese schools, believed in regarding the simultaneous existence of opposites. The Chinese dialectical yin yang model (Jiang 2013) holds that yin and yang are two distinct cosmic forces that are, at the same time, opposite to each other and interdependent, always working together to keep the universe in balance.

According to the Yin Yang philosophy, all universal phenomena are shaped by the integration of two opposite cosmic energies, namely Yin and Yang. Yin represents the 'female' energy, such as the moon, night, weakness, darkness, softness, and femininity; while Yang stands for 'male' energy, such as the sun, day, strength, brightness, hardness, and masculinity (Fang 2012, 31). Since all elements of the universe are made up of $y i n$ and yang, human beings are, at one and the same time, made up of positive and negative aspects. The guiding principle of this concept is that these two elements together bring about well-being, happiness, and emancipation. Therefore, well-being can be achieved if one focusses on positive and hopeful aspects, even amidst unfortunate situations. This belief instils an optimistic outlook towards life 
because nothing is absolutely good or bad, nor are bad times going to last forever. This attitude to life would bring about balance in people's minds. The concept of balance in everything was advocated by Taoism. For example, to be successful, one should not strive to be always successful, a rich person must not hoard up, but share their wealth with the poor. Thus, the idea of 'golden mean' became very important in the cultural ethos of the Chinese people, which led them to exercise a sense of balance in everything (Jiang 2013).

The Indian understanding of the co-existence of sukha (happiness) and dukha (sadness) as composite elements of well-being has been well recorded (Mishra 2017; Singh Raina and Sahni 2017). While sukha signifies all favourable experiences, dukha signifies the unfavourable ones; consequently, all sukha experiences cause happiness, and dukha experiences bring about suffering and sadness. In Indian philosophy, in order to describe material and day-to-day happiness, many terms such as santosha (happiness), hashya (joy), tripti (satisfaction), arogyam (good health) and shubha (to shine) as well as those which describe spiritual happiness, such as ananda (bliss) and sthirpragya (stable intellect) are utilised (Singh, Raina and Sahni 2017, 118). Furthermore, Indian vedic literature contends that human beings must be characterised by sat-chit-ananda, and their sole purpose in life must be to attain param ananda which means, permanent happiness (Banavathy and Choudry 2014).

This simultaneity is well manifested in ideas regarding collectivism and individualism. Indian understanding of its cultural make-up has progressed, and experts say that while Indian culture is predominantly collectivist (Bhawuk 2011; Triandis 1995), others contend that there is a high percentage of individualistic dimensions as well (Jha and Singh 2011; Sinha and Tripathi 1994). It is true that even today people consider Indian society to be collectivist where groups are bound together and mutually oblige each other for various reasons. However, we also see a gradual change taking place in India today. People tend to possess both individualistic and collectivist characteristics (Sinha and Tripathi 1994).

Thus, the Indian concept of balance is concerned with physical, social, metaphysical, ecological, psychological, and spiritual levels of human existence. This is indeed the crux of ecological well-being; a harmonious and integrated relationship between human beings and the ecological system that surround them. This mutually enriching relationship should cater to a just, sustainable, and enhancement of present, as well as future generations. Ultimately, this sense of balance helps people to cultivate positive attitudes when they begin "reflecting on the transitory, unsatisfying nature of hedonic pleasures, and by identifying and developing the inner causes of genuine well-being" (Wallace and Shapiro 2006, 694).

\section{Conclusion}

We have, therefore, seen that the Indian conceptualisation of PWB is centred around the concept of balance. A sense of balance signifies that attaining happiness can at best be a minor goal; the real goal is to experience well-being that is founded on one's mental balance and contentment with life. A comprehensive model of well-being advocated by Keyes (2003), comprised emotional, psychological and social well-being as its elements. Including ecological well-being as the fourth element of this model would enhance the symbiotic relationship between people and the ecological system that sustains them.

Indian philosophical and psychological thought offers a worldview of well-being that is inclusive, integrated, and balanced. Such a worldview rather than being lopsided, is at the centre of caring for financial, political, ethical, and relational dimensions of our society. When such balance is achieved, people can derive lasting happiness from even simple and day-to-day pleasures of life, such as creating works of art and music, sharing 
fun and laughter with loved ones, and raising a family. More importantly, every human person must constantly strive to integrate all these elements, in order to arrive at happiness and well-being.

Author Contributions: Conceptualisation, Z.F., J.J.S. and G.C.; Resources, J.J.S.; Writing - Original Draft Preparation, J.J.S.; Writing - Review \& Editing, Z.F., J.J.S. and G.C. All authors have read and agreed to the published version of the manuscript.

Funding: This research received no external funding. Institutional Review Board Statement: Not applicable.

Conflicts of Interest: The authors declare no conflict of interest.

\section{References}

Anuradha, Mv, and Yln Kumar. 2015. "Trigunas in organizations: Moving toward an East-West synthesis." International Journal of CrossCultural Management 15(2): 195-214. https://doi. org/10.1177/1470595815594636.

Banavathy, Vinayachandra, and Anuradha Choudry. 2014. "Understanding happiness: A Vedantic perspective." Psychological Studies 59: 141-152. https://doi.org/10.1007/s12646-013-0230-x.

Bhawuk, Dharm P.S. 2011. Spirituality and Indian Psychology: Lessons from the Bhagavad-Gita. Springer: Science+Business Media.

Biswas, Malay. 2010. "In search of personality inventory for Indian managers: An application of structural equation modelling." Journal of Services Research 10(1): 101-23.

Bradburn, M. Norman. 1969. The structure of psychological well-being. Chicago: Aldine.

Bunnin, Nicholas, and Jiyuan Yu. 2004. The Blackwell dictionary of Western Philosophy. Malden: Blackwell Publishing.

Caplan, Robert D. 1987. "Person-environment fit theory and organizations: Commensurate dimensions, time perspectives, and mechanisms." Journal of Vocational Behaviour 31: 248-267.

Chen, Yu-Hsi. 2006. "The way of nature as a healing power". In Handbook of multicultural perspectives on stress and coping, edited by Paul T. Wong and Lilian C.J. Wong, 91-103. New York: Springer.

Christopher, John Chambers. 1999. "Situating psychological well-being: Exploring the cultural roots of its theory and research." Journal of Counselling \& Development 77: 141-152.

Diener, Ed, and Eunkook M. Suh. 2000. Culture and subjective well-being. Cambridge, Massachusetts: The MIT Press.

Diener, Ed. 1984. "Subjective well-being". Psychological Bulletin 95(3): 542-575.

Edwards, Jeffrey R., and Cary L. Cooper. 2013. "The person-environment fit approach to stress: Recurring problems and some suggested solutions." Journal of Organisational Behaviour 11(4): 293-307. https://doi.org/10.1002/job.4030110405.

Fang, Tony. 2012. "Yin Yang: A New Perspective on Culture." Management and Organization Review 8(1): 25-50. https:/doi. org/10.1111/j.1740-8784.2011.00221.x.

Francis, Leslie J., Andrew Village, Deborah Bruce, and Cynthia Woolever. 2015. "Testing the balanced affect model of clergy work-related psychological health: Drawing on the U.S. Congregational Life Survey." Research in the Social Scientific Study of Religion 26: 237-249.

Francis, Leslie J., Patrick Laycock, and Giuseppe Crea. 2017. "Assessing clergy work-related psychological health: Reliability and validity of the Francis Burnout Inventory." Mental Health, Religion $\mathcal{E}$ Culture 20(9): 1-11. https://doi.org./10.1080/1367 4676.2017.1373333.

Francis, Leslie J., Peter Kaldor, Mandy Robbins, and Keith Castle. 2005. "Happy but Exhausted? Work-related psychological health among clergy." Pastoral Sciences 24(2): 101-120.

Heine, Steven J., and Darrin R. Lehman.1995. “Cultural variation in unrealistic optimism: Does the West feel more vulnerable than the East?" Journal of Personality and Social Psychology 68(4): 595607. https://doi.org/10.1037/0022-3514.68.4.595.

Ho, Violet T., and Jeffrey M. Pollack. 2014. "Passion isn't always a good thing: Examining entrepreneurs' network centrality and financial performance with a dualistic model of passion." Journal of Management Studies 51(3): 433-59. https://doi. org/10.1111/joms.12062.

Houlfort, Nathalie, Frederick L. Philippe, Robert J. Vallerand, and Julie Menard. 2014. "On passion and heavy work investment: Personal and organizational outcomes." Journal of Managerial Psychology 29(1): 25-45. https://doi.org/10.1108/ JMP-06-2013-0155. 
Huta, Veronika, and Richard M. Ryan. 2010. "Pursuing pleasure or virtue: The differential and overlapping well-being benefits of hedonic and eudaimonic motives." Journal of Happiness Studies 11: 735-762. https://doi.org/10.1007/ s10902-009-9171-4.

Huta, Veronika. 2018. "Eudaimonia versus Hedonia: What Is the Difference? And Is It Real?" International Journal of Existential Psychology \& Psychotherapy. Special Issue, Proceedings of the 2016 Meaning Conference.

Irwin, Terence H. 1999. Nicomachean Ethics ( $2^{\text {nd }}$ ed.). Indianapolis: Hackett.

Jha, Mukesh. 2009. "Personality: A yogic conception". Indian Journal of Social Sciences Research 6(1): 39-45.

Jiang, Xinyan. 2013. "Chinese dialectical thinking - the yin yang model." Philosophy Compass 8(5): 438-446. https://doi.org/10.1111/phc3.12035.

Joshanloo, Mohsen. 2014. "Eastern conceptualization of happiness: Fundamental differences with Western views." Journal of Happiness Studies 15(2): 475-493. https://doi.org/10.1007/ s10902-013-9431-1.

Keyes, Corey L.M. 2002. "The mental health continuum: From languishing to flourishing in life." Journal of Health and Social Behaviour 43(2): 207-222. https://doi.org/10.2307/3090197.

Kitayama, Shinobu, Hazel Rose Markus, and Masaru Kurokawa. 2000. "Culture, emotion, and wellbeing: Good feelings in Japan and the United States." Cognition and Emotion 14(1): 93-124.

Kraut, Richard. 2015. "Aristotle on well-being”. In The Routledge Handbook of Philosophy of WellBeing, edited by Guy Fletcher, 20-28. London: Routledge.

Lavigne, Genevieve L., Jacques Forest, and Laurence Crevier-Braud, 2012. "Passion at work and burnout: A two-study test of the mediating role of flow experiences." European Journal of Work \& Organizational Psychology 21(4): 518-46. https:// doi.org/10.1080/1359432X.2011.578390.

Lazarus, Richard S. 1993. "From psychological stress to the emotions: A history of changing outlooks." Annual Review of Psychology 44: 1-21.

Markus, Hazel Rose, and Shinobu Kitayama. 1991. "Culture and the self: Implications for cognition, emotion, and motivation."
Psychological Review 98: 224-253. https://doi. org/0.1037/0033-295X.98.2.224.

Mishra, Girishwar. 2017. "Nature and nurture of wellbeing". In Psychological well-being: correlational and intervention studies, edited by K. Ravichandra, Chintalapuri Beena and Renuka Regani (Eds), (vol. 1). New Delhi, India: Global Vision Publishing House.

Myers, David G. 2000. "The funds, friends, and faith of happy people." American Psychologist 55(1): 56-67. https://doi.org/10.1037//0003-066X.55,1.56.

Oishi, Shigehiro. 2018. "Culture and subjective wellbeing: Conceptual and measurement issues." In Handbook of well-being, edited by Ed Diener, Shigehiro Oishi, and Louis Tay. Salt Lake City: DEF Publishers. https://nobascholar.com/chapters/46/ download.pdf.

Raju, Poolla Tirupati. 1992. The philosophical traditions of India. New Delhi: Motilal Banarasidass.

Ricard, Matthieu. 2011. “The Dalai Lama: Happiness from within." International Journal of Wellbeing 1(2): 274-290. https://doi.org/10.5502/ijw.vli2.9.

Ryff, Carol D. 1989. "Happiness is everything, or is it? Explorations on the meaning of psychological well-being." Journal of Personality and Social Psychology 57: 1069-1081. https://doi. org/10.1037/0022-3514.57.6.1069.

Ryff, Carol D., Gayle D. Love, Yuri Miyamoto, Hazel Rose Markus, Katherine B. Curham, Shinobu Kitayama, Jiyoung Park, Norito Kawakami, Chiemi Kan, and Mayumi Karasawa. 2014. "Culture and the promotion of well-being in East and West: Understanding varieties of attunement to the surrounding context." In Increasing psychological well-being in clinical and educational settings: Interventions and cultural contexts, edited by Giovanni Andrea Fava, and Chiara Ruini, 1-19. Dordrecht, Netherlands: Science+Business Media. Salagame, Kiran Kumar. 2003. "An Indian conception of well-being." In Proceedings of European Positive Psychology Conference, edited by John Henry. Leicester: British Psychological Society. Accessed October 18, 2021. https://www.academia. edu/39364812/AN_INDIAN_CONCEPTION_OF_ WELL_BEING_1.

Salagame, Kiran Kumar. 2004. "Perspectives on wellbeing in the Indian tradition." Journal of Indian Psychology 22(2), 63-72. 
Salagame, Kiran Kumar. 2006. "Happiness and wellbeing in Indian tradition." Psychological Studies 51(2): 105-112.

Salagame, Kiran Kumar. 2016. "Meaning and well-being: Indian perspectives." Journal of Constructivist Psychology 30(1): 63-68. https:// doi.org/10.1080/10720537.2015.1119087.

Seligman, Martin E.P. 2002. Authentic happiness: Using the new positive psychology to realize your potential for lasting fulfilment. New York: Free Press.

Seligman, Martin E.P. 2011. Flourish: A visionary new understanding of happiness and well-being. New York: Free Press.

Selye, Hans. 1965. "The stress syndrome." The American Journal of Nursing 65(3): 97-99. https://doi.org/10.2307/3453119.

Shamasundar, Channapatna. 2008. "Relevance of ancient Indian wisdom to modern mental health - A few examples." Indian Journal of Psychiatry 50(2): 138-143.

Sharma, Suhani, Adha Singh, and Sakshi Mehrotra. 2016. "Sattva guna as a predictor of wisdom and psychological well-being." The International Journal of Indian Psychology 4(1): 158-169.

Shukla, Priyanka. 2016. "Positive psychology, Indian psychology and spirituality." Dev Sanskriti Interdisciplinary International Journal 7: 12-26. https://doi.org/10.36018/dsiij.v7i0.72.

Singh, Balbinder. 2019. "Refurbished ancient Indian thought in contemporary clinical psychology." $E C$ Psychology and Psychiatry 8(4): 299-307.

Singh, Kamlesh, Anjali Jain, Jasleen Kaur, Mohita Junnarkar, and Alena Slezackova. 2016. "Crosscultural differences on Gunas and other wellbeing dimensions." Asian Journal of Psychiatry 24: 139-146. https://doi.org/10.1016/j.ajp.2016.09.001.

Singh, Kamlesh, Mahina Raina, and Pooja Sahni. 2017. "The concept and measure of Sukha-Dukha: An Indian perspective on well-being." Journal of Spirituality in Mental Health 19(2): 116-132. https://doi.org/10.1080/19349637.2016.1231604.

Sinha, Durganand and Rama Tripathi. 1994. "Individualism in a collectivist culture: A case of co-existence of opposites." In Individualism and Collectivism: Theory, method, and applications, edited by Uichol Kim, Harry Triandis, Cigdem Kagitcibasi, Sang-Chin Choi, and Gene Yoon, 123136. Thousand Oaks: Sage.

Sinha, Durganand. 1990. "Concept of psycho-social well-being: Western and Indian Perspectives." NIMHANS Journal 8(1): 1-11.

Tandon, Smriti. 2016. "Exploring well-being in Indian context." Indian Anthropologist 46(1): 6378. Accessed 18.10.2021 https://www.jstor.org/ stable/43899793.

Thorgren, Sara, Joakim Wincent, and Charlotta Sirén. 2013. "The influence of passion and work-life thoughts on work satisfaction." Human Resource Development Quarterly 24(4): 469-92. https://doi. org/10.1002/hrdq.21172.

Triandis, Harry C. 1995. Individualism and collectivism. Boulder: Westview.

Vallerand, Robert J., Céline Blanchard, Geneviève A. Mageau, Richard Koestner, Catherine Ratelle, Maude Léonard, Marylène Gagné, and Marsolais Josée. 2003. "Les passions de l'âme: on obsessive and harmonious passion." Journal of Personality and Social Psychology 85(4): 756-767. https://doi. org/10.1037/0022-3514.85.4.756.

Van Egmond, N.D. and De Vries, H.J. M. 2011. "Sustainability: The search for the integral worldview." Futures 43: 853-867. https://doi. org/10.1016/j.futures.2011.05.027.

Wallace, B. Alan, and Shauna L. Shapiro. 2006. "Mental balance and well-being: Building bridges between Buddhism and Western psychology." American Psychologist 61(7): 690-701. https://doi. org/10.1037/0003-066X.61.7.690.

Waterman, Alan S. 1990. “The relevance of Aristotle's conception of eudaimonia for the psychological study of happiness." Journal of Theoretical and Philosophical Psychology 10(1): 39-44. https://doi. org/10.1037/h0091489.

World Health Organisation. 2001. Strengthening mental health promotion. Geneva: World Health Organisation (Fact sheet, No. 220). 